\title{
The Relationship of Strengthening Character Education (PPK) Towards Mathematics Learning Outcomes in Class IV
}

\author{
Made Kusuma Wardani ${ }^{1 *}$, I Made Suarjana ${ }^{1}$, Ndara Tanggu Renda ${ }^{1}$ \\ ${ }^{1}$ Primary School Teacher Education Study Program, Department of Basic Education, Ganesha University of \\ Education, Singaraja, Indonesia \\ "Corresponding author. Email: sumawardani68@ gmail.com
}

\begin{abstract}
The attitude of students who play when learning activities take place, cheat during tests, do not bring stationery, do not do homework, and are not obedient to school discipline rules when learning Mathematics can cause low Mathematics learning outcomes for grade IV students. Therefore, this study aimed to determine the relationship between strengthening character education and learning outcomes of fourth grade elementary school students. This research was an Expost-Facto study by correlating the strengthening of variable character education $(\mathrm{X})$ and variable mathematics learning outcomes $(\mathrm{Y})$. The population in this study were all class IV students as many as 202 students. The number of samples in this study were 108 students obtained through saturated sampling technique. The data collection method in this study was to use a questionnaire to obtain data on the effect of strengthening character education and document recording to obtain the value of Mathematics learning outcomes for fourth grade elementary school students. The analysis prerequisite tests in this study were the normality test of the data distribution, the linearity test, and the hypothesis testing using simple regression techniques. The analysis of this research showed that the $r$ table value can be obtained with the degrees of freedom $(\mathrm{df}=\mathrm{N}-2)$. At a significance level of $5 \%$ and $\mathrm{df}=108-2=116$, the $\mathrm{r}$ table is 0.189 , while rcount $=0.98$. Because rcount $>$ rtabel, this means that there is a significant relationship between strengthening character education on Mathematics learning outcomes of Grade IV Elementary School Students. The implication of strengthening character education in Mathematics learning is teachers have the opportunity to increase character values such as discipline, honesty, hard work, creativity and responsibility.
\end{abstract}

Keywords: Character Education, Learning Outcomes

\section{INTRODUCTION}

Education is the main factor that plays a role in shaping the human personality. In this life, education takes the greatest role in shaping a person's character and character which is used for the survival of the nation and state. Such statement is stated in Law Number 20 of 2003 concerning the Goals of National Education, Article 3 which mentions that the purpose of education is to function to develop abilities and shape character of students' so that they become human beings who are faithful and devoted, noble, healthy, knowledgeable, competent, creative, be independent, and become democratic and responsible citizens.

In order to achieve these educational goals, one way that can be used is to increase the Strengthening of
Character Education or what is called PPK. PPK can develop students in having ethics, responsibility, and concern. The most appropriate stage to implement PPK is at the primary school education level [11]. It is as stated in Perpres number 87 of 2017 concerning strengthening of PPK in which PPK is described in detail by Laksono [13] and can be carried out through: 1) planning the implementation of character building which includes routine school activities, spontaneous activities and methods used in character building. 2) the process of implementing character building is carried out by realizing the planning program for religious activities, order and learning, and 3) activities that are realized spontaneously such as saying greetings, greeting and saying thanks. 
This is due to the fact that PPK has a goal to improve the quality of education and outcomes that lead to the achievement of character building and noble character of students as a whole integrated and balanced. Thus, the education system in schools does not only focus on mastery of academic cognitive (knowledge), but can apply affective (attitudes) and psychomotor (skills) in academic students. Character education that is implemented in schools can be carried out through daily learning. This means that character education can strengthen existing subjects, for example by implementing the daily lives of students [9]. In this regard, character education in elementary schools can take place in learning mathematics. Mathematics has an important role in various disciplines and can advance human thinking. Through the cultivation of character education, it is hoped that students can practice knowledge in a balanced manner. Masnur Muslich [15] states character education is character education plus, which involves aspects of the theory of knowledge (cognitive), feelings (feeling), and action (action). Thomas Lickona in Masnur Muslich [15] mentions that without these three aspects, character education will not be effective, and its implementation must be carried out systematically and continuously. The purpose of character education according to Omeri [16] is to develop the affective potential of students according to cultural values and national character, develop commendable habits and behavior of students, instill a spirit of leadership and responsibility of students as the nation's next generation, develop a spirit of leadership students become human beings who are independent, creative, have a national perspective and develop a school life environment as a learning environment that is safe, honest, full of creativity and friendship as well as with a strong and strong sense of nationality.

Mathematics is a universal science that underlies the development of modern technology because the rapid development in the fields of technology, information and communication is based on the development of mathematics in the fields of number theory, algebra, analysis, systematic, critical, and creative and able to work together [10]. Thus, the teacher must act more as a guide so that education is indirectly truly embedded in the learning. For example, character education can be obtained by students by having the ability to solve various problems that exist in everyday life that allow students to think rationally. This is in line with Soedjadi in Abdul Rahman [1] who states that mathematics as a science has characteristics, namely having abstract objects, deductive thinking patterns, relying on agreement, paying attention to what is the topic of conversation (the universe of conversation), having symbols that are empty of meaning and consistent in the system.

Based on this, students are not only expected to be able to answer questions in books and questions given by the teacher, but students must have an understanding of the concepts being studied. According to Permendiknas No. 22 (2006: 148), it is stated that the standard content of mathematics subject units in SD / MI has the aim of enabling students to have the ability to understand mathematical concepts, explain the relationship between concepts and multiply concepts or logarithms in a flexible, accurate, efficient and precise way in solving problems, using reasoning on patterns and properties, perform mathematical manipulations in making generalizations, compile evidence or explain mathematical ideas and statements, solve problems which include the ability to understand, design mathematical models, solve models and interpret solutions obtained, communicate ideas and symbols, tables, diagrams, or other media to clarify the situation or problem and have an attitude of appreciating the usefulness of mathematics in life.

Based on the objectives of learning mathematics mentioned previously, mathematics has very important goals to form a mindset. Indah [8] states clearly that learning mathematics in schools has a role that can form attitudes that can be balanced with the mindset. Thus, the relationship between mathematics and strengthening character education is a learning process that involves various elements (fields of study, students, teachers, and their environment) [20]. The series of learning processes is carried out in the form of involvement in informal education, compliance with their participation in education. formal and / or formal education. This learning ability distinguishes humans from other creatures. Pane (2017) states that learning shows activities carried out by someone who is conscious or deliberate himself.

Thus, learning is an activity carried out by humans, consciously or unconsciously, to gain abilities, skills and attitudes that can lead to better changes in themselves. In this change, there exist a process from not knowing to knowing. The aspect that changes in this case is not only the aspect of knowledge, but also the attitude and skills. By increasing the ability of human skills, it will be easier for humans to live later in a career, while changes in attitudes means that it will be easier for humans to interact in society because human attitudes are related to the character they have. If someone has good character, he will be easily accepted in society.

Strengthening Character Education is an effort to strengthen character and implement moral values such as religion, independence, mutual cooperation and student integrity. Strengthening Character Education (PPK) according to Presidential Decree Number 87 of 2017 is defined as an educational movement in schools to strengthen student character through harmonization of heart (ethics), feeling (aesthetics), thinking (literacy), and sports (kinesthetic) with support involving the public and cooperation between schools, families and communities 
that are part of the National Movement for the Mental Revolution. Wahyudi [21] stated that the movement to implement the strengthening of PPK can be carried out with class-based PPK, culture-based character education, and community-based character education.

Especially in mathematics learning activities, teachers can integrate PPK through the choice of teaching methods, how to manage the class during the teaching and learning process as well, PPK can be done by integrating values in subjects, both in an integrative thematic approach for SD. In a series of teaching and learning processes in the classroom, teachers have free opportunities to develop the character of students. The teacher can choose a part of the subject or theme of the lesson to be integrated with the character development of students. The learning method chosen can be a medium for character development. When managing a classroom, the teacher has the opportunity to develop character through his actions and speech during the learning process.

Based on the reality in the field when interviews and observations were carried out, the implementation of Mathematics learning in grade IV SD on October 21 October 26 2019, it is implied that the teacher has carried out learning activities that apply character values to mathematics learning which is already stated in the RPP. The teacher has tried to use learning methods, learning strategies, learning media that are used to implement Table 1. IV Grade Students' Mathematical Middle Test Score Data character education and improve student learning outcomes, but the implementation has obstacles, namely the behavior of students that do not reflect character values such as the attitudes of students who play around during learning activities take place, cheat on tests, do not bring stationery, do not do homework, and is not being obedient to school rules and regulations. This has an impact on students' mathematics learning outcomes. Learning outcomes are the abilities or changes experienced by students after receiving experiences in learning. Learning outcomes can be interpreted as behavior which includes the cognitive, affective, and psychomotor domains, the cognitive domain is related to thinking skills, the affective domain is related to attitudes, and the psychomotor domain with physical movement skills [5]. The meaning of learning outcomes, namely the changes that occur in students, whether related to cognitive, affective, and psychomotor aspects as a result of learning activities (Susanto, 2013: 5). In addition, Hikmawati [6] states that mathematics learning outcomes are a measure that states the level of ability in the form of mastery of Mathematics subject matter, skills, attitudes achieved by a person as a result of the material studied during a certain period of time.

Based on the results of data collection on the Middle Semester Test scores in mathematics in grade IV, there were students who obtained Middle Semester Test scores under the KKM, the following data is shown in table 1.

\begin{tabular}{|c|c|c|c|c|c|}
\hline \multirow{2}{*}{ No } & Public Elementary School Cluster 3 & \multirow{2}{*}{$\begin{array}{c}\text { KKM } \\
\text { Tejakula District }\end{array}$} & $\begin{array}{c}\text { Number of } \\
\text { Students }\end{array}$ & \multicolumn{2}{|c|}{ Amount } \\
\cline { 5 - 6 } & Sd Negeri 1 Tejakula & 70 & 35 & 12 & 23 \\
\hline 1 & Sd Negeri 2 Tejakula & 70 & 35 & 22 & 13 \\
\hline 2 & Sd Negeri 3 Tejakula & 65 & 20 & 8 & 12 \\
\hline 3 & Sd Negeri 4 Tejakula & 63 & 21 & 10 & 11 \\
\hline 4 & Sd Negeri 5 Tejakula & 68 & 29 & 11 & 18 \\
\hline 5 & Sd Negeri 6 Tejakula & 68 & 32 & 12 & 20 \\
\hline 6 & Sd Negeri 7 Tejakula & 63 & 16 & 7 & 10 \\
\hline 7 & Sd Negeri 8 Tejakula & 63 & 13 & 5 & 8 \\
\hline 8 & Total & & 202 & 87 & 115 \\
\hline
\end{tabular}

Based on Table 1, of all students, there are still 115 students $(56.93 \%)$ who were still below the KKM, while only 87 students $(43.07 \%)$ were above the KKM. Referring to the problems encountered in the field, the solution that can be offered is to increase the relationship by strengthening character education on mathematics learning outcomes. Maisaro [14] states that strengthening character education is a formation of one's behavior in order to have character that is inherent in students. Therefore, education does not only hone intellectuals, but education has a balance towards strengthening character education to overcome moral decline among students, for example speaking dirty, lying and being brave to teachers. The concept of character education is that character can be formed as a habit in learning situations when providing learning material and learning evaluation [22]. Strengthening character education is needed because with character education, the suitability of education with subjects has a relationship with learning success and achievement.

This solution is supported by the success of research conducted by Albertus [3] showing that students give positive responses to character education-based learning. Then the research conducted by Holly [7] shows that there is a positive relationship between character and student mathematics learning outcomes, there is a positive relationship between learning creativity and student mathematics learning outcomes, and there is a 
positive relationship between character and student creativity with Mathematics learning outcomes of students. The results of research from Kusuma [12] indicates that the application of character education can be seen from the application of character education in the implementation of learning mathematics instilled through preliminary, core and closing activities. Character values that can be applied in the learning include discipline, honesty, independence, hard ape, tolerance, respect for achievement, democratic and creative. Implementation of strengthening character education can be carried out on a culture-based basis when carrying out learning in class. Teachers can choose learning methods by integrating values in subjects [21]. Class management that can be carried out by the teacher when instilling the values of the subject can be done with actions or speech during the learning process. Thus, the Strengthening of Character Education (PPK) can strengthen the character of moral values such as religion, independence, mutual cooperation and student integrity. Based on these descriptions, it is deemed necessary to conduct ex post facto research to determine the relationship between strengthening character education and student mathematics learning outcomes, so a study was conducted with the title "The Relationship of Strengthening Character Education on Mathematics Learning Outcomes of Class IV SD Students".

\section{METHOD}

The data collection method used in this study is questionnaire. Questionnaire is a data collection technique that is carried out by giving a set of questions or written statements to respondents to answer [17]. The questionnaire was given to grade IV SD students to find out the character value. The type of statement in the questionnaire was closed, which is a statement that expects a short answer or expects the respondent to choose an alternative answer from each available statement. The data was collected by using the documentation method, namely by systematically viewing the records of the documents needed in the study. This method was used to collect data about the mathematics learning outcomes of grade IV elementary school students. Research is basically a measurement effort, so the measuring instrument in research is called a research instrument. Sugiyono [18] states that the research instrument is a tool used to measure observed natural and social phenomena. Based on this, this study used two instruments in data collection, namely: the instrument of learning outcomes in mid-semester test scores and the instrument of character education. The data collection of students 'mathematics learning outcomes was taken from the Middle Semester Deuteronomy score as a measuring tool to determine students' ability in understanding mathematics material obtained at school and the character values instrument in the form of a questionnaire. The answer to each item of the character score questionnaire carried out by students used a measurement scale called the Likert scale. The Likert scale is used to measure attitudes, opinions, and perceptions of a person or group of people about social phenomena.

This research was an Expost-Facto study by correlating the strengthening of variable character education (X) and variable mathematics learning outcomes (Y). The population in this study were all fourth grade students, totaling 202 students. The number of samples in this study were 108 students obtained through saturated sampling technique. The technique used in this research is descriptive statistics. Sukardi [19] states that descriptive research does not manipulate variables and does not determine events that will occur, and usually involves events that are currently occurring. Furthermore, the analysis requirements test was intended to test whether the data that had been obtained met the prerequisites for analysis with predetermined techniques. Related to this, the analysis prerequisite test was analyzed to test the normality of the data distribution, linearity test, and hypothesis testing.

\section{RESULTS}

The results of this study describe the data on student mathematics learning outcomes obtained through midterm test scores in fourth grade elementary school students as variables (Y) and character education data obtained through questionnaires as independent variables (X). Data regarding the Mathematics learning outcomes of Class IV Elementary School Students was obtained through the document recording method. The value data used was the mid-semester test score for Elementary School Students Class IV in the even semester 2019/2020. The number of samples used was adjusted to the sample in the study, namely 108 students. Mathematics learning outcomes of fourth grade elementary school students, regarding the frequency distribution of Mathematics learning outcomes in general, showed that there was a range from the lowest value of 54 to the highest value of 93 . It was known that the highest number of frequency values was in interval 3 , namely the range of 64-68, and the lowest number of frequencies. in the 8th interval, the range 89-93. If confirmed by comparing the average number with the criteria for the Standard Reference Assessment (PAP) scale of 5 conversion guidelines according to Agung [2], the criteria for student mathematics learning outcomes were quite good. Data regarding the strengthening of character education for fourth grade elementary school students was obtained through distributing questionnaires to strengthen character education. The number of samples determined to fill out the character education strengthening questionnaire was 108 students, who were instructed to answer 32 items with a rating scale provided. Description of the data on the 
strengthening of character education for Class IV Elementary School Students, namely, data on strengthening the character education of Class IV Elementary School Students, indicated that the value of the mathematics learning outcomes of grade IV students in general was the 4th interval, namely the range 70-75 and the lowest number of frequencies is -8 which was in the 94-99 range. If confirmed by comparing the average number with the criteria for the Standard Reference Assessment (PAP) scale of 5 conversion guidelines according to Agung [2], the criteria for student mathematics learning outcomes were in poor criteria.
Assumption testing was intended to test whether the data that had been obtained met the prerequisites for analysis with predetermined techniques. In connection with this, the analysis prerequisite test was conducted to test the normality of data distribution, linearity test, and hypothesis testing. The distribution normality test was carried out to present that the sample really came from a population that was normally distributed. The data normality test was carried out by the Chi-Square (X2) test. 2. Data Normality Test Results of Mathematics Learning Outcomes and Strengthening Character Education are as follows.

Table 2. Results of Normality Test of Mathematics Learning Outcomes and Strengthening Character Education Data

\begin{tabular}{|c|c|c|c|c|c|}
\hline No & Variable & Chi-Square Count & Information & $\begin{array}{c}\text { Chi-Square } \\
\text { Table }\end{array}$ & Conclusion \\
\hline $\mathbf{1}$ & $\begin{array}{c}\text { Mathematics Learning } \\
\text { Outcomes }(Y)\end{array}$ & 17.73 & \multirow{2}{*}{$<$} & $\begin{array}{c}\text { Normal } \\
\text { distribution }\end{array}$ \\
\hline $\mathbf{2}$ & $\begin{array}{c}\text { Strengthening Character } \\
\text { Education }(\mathrm{X})\end{array}$ & 13.11 & 131.144 & \\
\hline
\end{tabular}

These results are in table 2. Results of the Normality Test of Mathematics Learning Outcomes and the strengthening of character education were then consulted to the chi-square table at the $5 \%$ significance level. Based on the $5 \%$ significance level with $\mathrm{dk}=$ number of rows 1 $=108-1=107$, the Chi-Square table price was 132.144 and the calculated Chi-Square was 17.73 so that it can be concluded that 2 count (17.73) $<2$ table (132.144). Because the resulting Chi-Square price was smaller than the Chi-Square table price, it can be concluded that Mathematics learning outcomes were normally distributed and the results of strengthening character education were consulted to the chi-square table at the $5 \%$ significance level. Based on the 5\% significance level with $\mathrm{dk}=$ number of rows $1=108-1=107$, the ChiSquare table price was equal to and the Chi-Square count Table 3. Anova Linearity Test was 13.11 , so it can be concluded that 2count (13.11) $<2$ table 132.144. Because the resulting Chi-Square price was smaller than the Chi-Square table price, it can be concluded that the results of students' democratic attitudes were normally distributed.

Linearity test was used to determine whether the relationship between two variables was linear. A linear relationship is characterized by an increase in the score on one variable followed by an increase in other variables as well. The following are the results of the linearity test of Mathematics learning outcomes for fourth grade elementary school students with strengthening character education shown in table 3 Anova Linearity Test as follows

\begin{tabular}{|c|c|c|c|c|c|c|c|}
\hline \multicolumn{8}{|c|}{ ANOVA Table } \\
\hline & & & $\begin{array}{l}\text { Sum of } \\
\text { Squares }\end{array}$ & df & $\begin{array}{l}\text { Mean } \\
\text { Square }\end{array}$ & $\mathbf{F}$ & Sig. \\
\hline \multirow{5}{*}{$\begin{array}{l}\text { Mathematics } \\
\text { Learning } \\
\text { Outcomes * } \\
\text { Strengthening } \\
\text { Character } \\
\text { Education }\end{array}$} & \multirow{3}{*}{$\begin{array}{c}\text { Between } \\
\text { Groups }\end{array}$} & (Combined) & 10510.000 & 37 & 284.054 & 126.918 & .000 \\
\hline & & Linearity & 10396.268 & 1 & 10396.268 & 4645.141 & .000 \\
\hline & & $\begin{array}{l}\text { Deviation } \\
\text { from } \\
\text { Linearity }\end{array}$ & 113.732 & 36 & 3.159 & 1.412 & .109 \\
\hline & \multicolumn{2}{|c|}{ Within Groups } & 156.667 & 70 & 2.238 & & \\
\hline & \multicolumn{2}{|c|}{ Total } & 10666.667 & 107 & & & \\
\hline
\end{tabular}

Based on the analysis in table 3 about Anova Linearity test, it is found that the Linearity significance is 0.000 ( $p<0.05)$ so that the strengthening of character education with mathematics learning outcomes has a linear relationship. While the significance of Deviation from linearity is $0.109(\mathrm{p}>0.05)$ so that the strengthening of character education and mathematics learning outcomes has a significant relationship. Testing the research hypothesis using product moment analysis, the results obtained value $=0.98$, which means that there is a relationship between strengthening character education and learning outcomes of fourth grade elementary school students. The value of $r$ table can be obtained with the degrees of freedom $(\mathrm{df}=\mathrm{N}-2)$, at the $5 \%$ significance 
level. And obtained df $=108-2=116$ and obtained $\mathrm{r}$ table of 0.189 , while $r$ count $=0.98$. Due to $r$ count $>r$ table, it can be stated that there was a significant relationship between strengthening character education on Mathematics learning outcomes of Class IV Elementary School Students. The implementation of Mathematics learning by applying Strengthening Character Education can be designed through syllabus and lesson plans [4].

Strengthening Character Education in Mathematics learning is designed through syllabus, lesson plans, and implementation of learning in class. Students who can carry out character values get good learning outcomes. Mathematics learning activities are carried out by integrating character values in the lesson plans. Character values applied in learning activities such as honesty, hard work, creativity, curiosity, independence and responsibility. The research results obtained indicated that it can shape students' thoughts related to ideas, processes, and reasoning, by reasoning that children can distinguish between good and bad things, useful, or not. Even with reasoning the child will be able to distinguish the action from the existing problem. Thus, stage by stage, the development of children's character begins to take shape. Khamidah [10] states through the cultivation of character education in Mathematics learning, students can practice knowledge in a balanced way both cognitive, affective, and psychomotor, and according to Holly [7] if students are able to adapt in class or in the learning process with characters that are already educated certainly the results of learning mathematics will increase. Based on this description, it can be concluded that there is a relationship between strengthening character education on the Mathematics learning outcomes of Class IV Elementary School Students.

\section{CONCLUSION}

Based on the results of the research and discussion, it can be concluded that there was a relationship between strengthening character education and learning outcomes of Class IV Elementary School Students. This can be seen from the analysis using the product moment with the results of learning mathematics having a correlation with strengthening character education. Based on the results of this study, it is shown that there was a significant relationship between strengthening character education on mathematics learning outcomes of fourth grade elementary school students. The following are suggestions for different parties. First, students should carry out attitudes that are in accordance with character values in order to improve mathematics learning outcomes. Second, teachers in elementary schools can provide Mathematics learning activities by integrating character values in the syllabus, RPP, and learning activities. Next, the principal can use as result of this research as policy material in improving the quality of mathematics learning carried out by teachers and facilitating all activities related to character education, and other researchers can develop this research by linking other subjects, methods, strategies, and models. other learning, so that later it will add to the repertoire of knowledge and insight into strengthening character education to improve student learning outcomes.

\section{REFERENCES}

[1] A. Rahman. Pendidikan Karakter Dalam Pembelajaran Matematika. Jurnal Pendidikan Matematika, vol. 5, 2016.

[2] A. A. G. Agung, Metodologi Penelitian Pendidikan. Aditya Media Publishing, 2014.

[3] A. N. C. Albertus, Pengaruh Pembelajaran Berbasis Pendidikan Karakter Terhadap Prestasi Belajar Siswa Pada Materi Himpunan di Kelas VII SMP Pangudi Luhur Boro Yogyakarta Tahun Ajaran 2015/2016, Dharma, 2016.

[4] K. Y. Dewi, Pendidikan Karakter Dalam Pembelajaran Matematika, Jurnal Pendidikan Matematika, vol. 2, 2015.

[5] Gading, et. al., Belajar dan Pembelajaran, Undiksha, 2018.

[6] Hikmawati, Peningkatan Hasil Belajar Matematika Melalui Penerapan Congruence Evaluation Model Pada Siswa Kelas VII MTs-Miftahul Ulum Guppi Datara Kecamatan Tompobulu Kabupaten Gowa.Prodi Pendidikan Matematika. Fakultas Tarbiyah dan Keguruan.Universitas Islam Negeri, Universitas Islam Negeri Alauddin Makasar, 2010.

[7] H. J. Patricia, Hubungan Antara Karakter dan Kreativitas Blajar Dengan Hasil BelajarMatematika Siswa, Jurnal Sains, vol. 5, 2017.

[8 P. M. S. Indah, Implementasi Pendidikan Karakter dalam Pembelajaran Matematika SMP di Kota Yogyakarta, Jurnal Riset Pendidikan Matematika, 4.

[9] S. Judiani 9n.d.), Implementasi pendidikan karaker di sekolah dasar melalui penguatan pelaksanaan kurikulum, Jurnal Pendidikan dan Kebudayaan, 9.

[10]N. Khamidah, Pendidikan Karakter Dalam Pembelajarn Matematika di SD Insan Teladan Desa Kalisuren Kecamatan Tahurlajang Kabupaen Bogor Jawa Barat, 2013.

[11]D. N. Khotimah, Implementasi Program Penguatan Pendidikan Karakter (PPK) Melalui Kegiatan 5s di Sekolah Dasar, Jurnal Ilmiah Kependidikan, 2, 2019. 
[12]A. T. Kusuma, Pendidikan Karakter Siswa Kelas XI DI SMA NEGERI 1 Moga Kabupaten Pemalang, Doctoral Dissertation, Universitas Negeri Semarang, 2016.

[13] T. H. Laksono, Implementasi Peraturan Presiden No 87 Tahun 2017 Tentang Penguatan Pendidikan Karakter di Sekolah Dasar Magelang, Doctoral Dissertation, Skripsi, Universitas Muhammadiyah Magelang, 2019.

[14] A. Maisaro, B. B. Wiyono, I. Arifin, Manajemen program penguatan pendidikan karakter di sekolah dasar, Jurnal Administrasi Dan Manajemen Pendidikan, 3, 2019.

[15]M. Muslich, Pendidikan Karakter Menjawab Tantangan Krisis Multidimensia, Bumi Aksara, 2011.

[16] N. Omeri, Pentingnya Pendidikan Karakter Dalam Dunia Pendidikan, Manajer Pendidikan, 2015.

[17] Rukaesih. et. al., Metodologi Penelitian Pendidikan, PT Raja Grafindo Persada, 2015.

[18] Sugiyono, Metode Penelitian Pendidikan Pendekatan Kuantitatif dan Kualitatif, Alfabeta, 2013.

[19] Sukardi, Metodologi Penelitian Pendidikan Kompetensi dan Praktiknya, Bumi Aksara, 2003.

[20]W. Suprih, Pendidikan Karakter Dalam Pembelajaran Matematika Di Sekolah Dasar, Jurnal Pendidikan Ke-SD-An, 2, 2017.

[21] Wahyudi, Prosiding Seminar Nasional Penguatan Pendidikan Karakter Pada Siswa Dalam Menghadapi Tantangan Global, 2019.

[22] H.Wijaya, H. Helaluddin, Hakikat Pendidikan Karakter, 2018. 